\title{
Decreased levels of genuine large free hCG alpha in men presenting with abnormal semen analysis
}

\author{
Christoph Zenzmaier ${ }^{1}$, Regine Gerth ${ }^{1}$, Matthias Gruschwitz ${ }^{2}$, Herbert Lindner ${ }^{3}$, Eugen Plas $^{4}$ and Peter Berger ${ }^{1 *}$
}

\begin{abstract}
Background: The pregnancy hormone human chorionic gonadotropin (hCG) and its free subunits (hCG alpha, hCG beta) are produced in the male reproductive tract and found in high concentrations in seminal fluid, in particular hCG alpha. This study aimed to elucidate changes in peptide hormone profiles in patients showing abnormal semen analyses and to determine the genuineness of the highly abundant hCG alpha.

Methods: Seminal plasma was obtained from 45 male patients undergoing semen analysis during infertility workups. Comprehensive peptide hormone profiles were established by a panel of immunofluorometric assays for hCG, hCG alpha, hCG beta and its metabolite hCG beta core fragment, placental lactogen, growth hormone and prolactin in seminal plasma of patients with abnormal semen analysis results $(n=29)$ versus normozoospermic men $(n=16)$. The molecular identity of large hyperglycosylated hCG alpha was analyzed by mass-spectrometry and selective deglycosylation.
\end{abstract}

Results: hCG alpha levels were found to be significantly lower in men with impaired semen quality (1346+/- 191 vs. $2753+/-533 \mathrm{ng} / \mathrm{ml}, P=0.022$ ). Moreover, patients with reduced sperm count had reduced intact hCG levels compared with normozoospermic men $(0.097+/-0.022$ vs. $0.203+/-0.040 \mathrm{ng} / \mathrm{ml}, P=0.028)$. Using massspectrometry, the biochemical identity of hCG alpha purified from seminal plasma was verified. Under nonreducing conditions in SDS-PAGE, hCG alpha isolated from seminal plasma migrated in a manner comparable with large free hCG alpha with an apparent molecular mass (Mr, app) of $24 \mathrm{kDa}$, while hCG alpha dissociated from pregnancy-derived holo-hCG migrated at approximately $22 \mathrm{kDa}$. After deglycosylation with PNGase F under denaturing conditions, all hCG alpha variants showed an Mr, app of $15 \mathrm{kDa}$, indicating identical amino acid backbones.

Conclusions: The findings indicate a pathophysiological relevance of hCG, particularly its free alpha subunit, in spermatogenesis. The alternative glycosylation pattern on the free large hCG alpha in seminal plasma might reflect a modified function of this subunit in the male reproductive tract.

\section{Background}

Male fertility abnormalities are diagnosed by physical examination, endocrine parameters and assessment of semen quality. Endocrine analyses include hormones of the pituitary testicular axis, i.e. pituitary-derived gonadotropins luteinizing hormone (LH), follicle stimulating hormone (FSH), total testosterone (TT) and free/bioavailable testosterone. Other hormones, such as prolactin (hPRL), estrogen, or stress hormones, are also important parameters of the male fertility workup.

\footnotetext{
* Correspondence: peter.berger@oeaw.ac.at

${ }^{1}$ Institute for Biomedical Aging Research, Austrian Academy of Sciences,

Rennweg 10, 6020 Innsbruck, Austria

Full list of author information is available at the end of the article
}

Apart from serum hormone levels, investigators sought molecular markers of spermatogenesis in seminal plasma. Such markers were anti-Mullerian hormone, inhibin B [1], and transferrin. Although a few attempts have been made to correlate human chorionic gonadotropin (hCG) and hCG-like molecules to spermatogenesis [2-9], the molecular heterogeneity of molecular hCG species in various body fluids, the lack of appropriate standards of hCG-variants, undefined molecular recognition profiles of immunoassay analyses and interpretation of marker profiles has, until recently, been too poor to do so [10] (the molecular structures of hCG and its variants are schematically depicted in Figure 1). The International Society of Oncodevelopmental Biology and

\section{Ciomed Central}




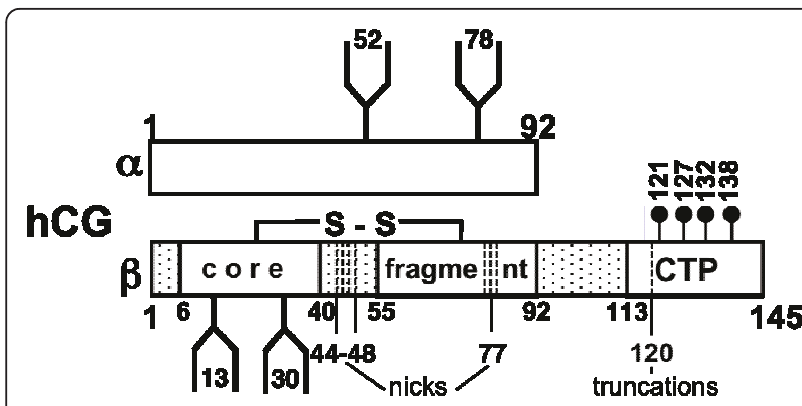

Figure 1 Schematic depiction of the molecular structures of the cystine knot growth factor hCG and of hCG-variants. hCG consists of an $\alpha$-subunit ( $h C G \alpha$ ) with 92 amino acids (aa) in length non-covalently linked to the $h C G \beta$-subunit (145 aa). Nicked hCG (hCGn) and nicked hCG $\beta$ (hCG $\beta n$ ) contain nicks in the region of aa hCG $\beta 44-48$ and rarely around aa 77 of hCG $\beta$. The most important metabolic product of hCG is the hCG $\beta$ core fragment (hCG $\beta c f$, which is composed of two peptides encompassing aa hCG $\beta 6-40$ and 55 to 92 covalently linked. The hCG-unique carboxyl-terminal peptide (CTP) is clipped and truncated hCG and hCG $\beta$ variants are generated (-CTPhCG and -CTPhCG $\beta$ ). There are a multitude of glycosylation variants involving both N-glycosylated ( $h C G \alpha$ aa 52 \& 78 , hCG $\beta$ aa 13 \& 30) and O-glycosylated carbohydrate antennae (hCG $\beta$ aa Ser 121, 127, 132, 138) $[41,42]$.

Medicine (ISOBM) has initiated and completed, as part of its Tissue Differentiation (TD) program, the international TD-7 Workshop on antibodies to hCG and hCGrelated molecules and recommended epitope combinations for 2-site immunoassays for the measurement and determination of members of the molecular hCG family [11]. With our selective panel of immunofluorometric assays (IFMAs) based on the reference monoclonal antibodies (mAbs) of the TD-7 Workshop [12], we previously investigated the abundance of hCG and hCGlike molecules in seminal plasma of healthy fertile men and found significant differences between the hCG marker profile and that of other hCG-containing physiological body fluids [13]. During pregnancy, the $\alpha / \beta$ heterodimer hCG is present in vast molar excess in serum, as is hCG $\beta / \mathrm{hCG} \beta \mathrm{cf}$ (hCG $\beta$ core fragment) in urine, but in seminal plasma, the subunit hCG $\alpha$ was by far the most prominent marker of the hCG molecular family, with concentrations as high as that found during pregnancy in extraembryonic coelomic fluid, and approximately 10,000-fold higher than in normal male serum. hCG $\beta$ and holo-hCG concentrations were found to be 1000-fold and 10,000-fold less than hCG $\alpha$, whereas hCG $\beta$ cf levels were mostly undetectable in seminal plasma [13].

In the present study, the local profile of endocrine parameters, i.e. hCG-like substances and the family of protein hormones prolactin (hPRL), growth hormone $(\mathrm{GH})$ and placental lactogen (PL), was analyzed in seminal plasma of men with abnormal semen analysis findings and compared to normozoospermic men to clarify a possible pathophysiological role of these hormones in spermatogenesis disorders. An important question was whether the highly abundant hCG $\alpha$ is genuine hCG $\alpha$ or a moderately-defined hCG $\alpha$-like substance. Thus, the glycosylation pattern of hCG $\alpha$, which has two N-glycosylation sites at $\mathrm{Asn}^{52}$ and $\mathrm{Asn}^{78}$ [14], was purified from seminal plasma and the isolated protein analyzed by mass-spectrometry.

\section{Methods}

\section{Determination of serum hormone levels}

All blood samples were obtained between 8 and 10 a.m. and were immediately transferred to the laboratory for further processing. Hormonal analyses included the determination of FSH, LH, TT and hPRL. FSH and LH analysis was performed using a standard two step immunoassay (Architect FSH, Abbott; ref. B7K750; Architect LH, Abbott; ref. 34-4522/R8). hPRL levels were determined by the two-step immunoassay Architect Prolactin (Abbott; ref. B7K760), TT levels by the Architect Testosterone Assay (Abbott; ref. B7K730). All assays were performed according to manufacturer's instructions.

\section{Semen samples}

Human semen samples were collected after 4 days of ejaculatory continence from 45 male patients undergoing semen analysis as part of an infertility workup at the Andrology Division of the Department of Dermatology, Univ. of Erlangen-Nuremberg, Germany, between 1995 and 1997. Semen samples were obtained and processed as recommended in the WHO Laboratory Manual for the Examination of Human Semen and Semen-Cervical Mucus Interaction [15]. None revealed the presence of antisperm antibodies in their seminal plasma or sera as shown by the immunobead technique [16]. The seminal fluid remaining after routine testing was aspirated from the spermatozoal pellet and stored at $-20^{\circ} \mathrm{C}$ until use. After thawing, the seminal fluids were centrifuged at 40,000 $\times$ g to remove residual debris and then assayed. All patients gave written informed consent.

\section{Semen analysis}

Semen analysis was performed by determination of $\mathrm{pH}$, liquefaction time, volume, total and progressive motility at $60 \mathrm{~min}$ after ejaculation, sperm/round cell/germ cell/leukocyte counts, and the total and specific head/midpiece/ tail percentage of abnormal forms according to the WHO criteria of 1995. Morphology was determined on methanol-fixed (2.5 $\mathrm{min})$ and giemsa-stained (10 min) sperm smears by light microscopy and by two independent observers by using the strict Kruger criteria. Viability of sperm was measured by eosin $\mathrm{Y}$ staining. The 
concentration of polymorphonuclear neutrophil white blood cells was measured by peroxidase staining.

Patients were grouped according to their semen analysis; abnormal semen results $(n=29)$ : oligoasthenoteratozoospermia (OAT, $n=7)$, asthenoteratozoospermia $(n=2)$, asthenozoospermia $(n=3)$, teratozoospermia $(n=1)$, oligozoospermia $(n=2)$, cryptozoospermia $(n=8)$, azoospermia $(n=6)$, and normozoospermic men $(n=16)$.

\section{Time-resolved immunofluorometric assays}

Generation and characterization of monoclonal Antibodies (mAbs) against intact hCG, hCG $\beta$, hCG $\beta$ cf, hCG $\alpha$ and FSH and GH, hPRL and PL has been described in detail [17-20]. The mAbs against hCG/hCG-variants were previously used as reference reagents in the international TD-7 Workshop on antibodies to hCG and hCG-related molecules [11]. Sensitive and specific IFMAs for hCG, free hCG $\alpha$, free hCG $\beta$ and the hCG $\beta$ cf, respectively, were developed on the basis of our panel of mAbs [21,22]. MAb pairs for each of the four IFMAs were selected on the basis of antigen specificity, epitope localization and compatibility [11,17,18,23-25].

IFMAs were performed as published previously $[26,27]$. Samples were diluted in $0.01 \mathrm{~mol} / 1 \mathrm{NaHCO}_{3}$ containing $0.1 \%$ bovine serum albumin (BSA).

The National Institute for Biological Standards and Control (NIBSC; South Mimms, UK) kindly provided the International Standards (IS) for hCG IS75/537, hCG $\beta$ IS 75/551, hCG $\alpha$ IS 74/569. Highly purified hCG $\beta$ cf was a gift by Drs. Klaus Mann and Rudy Hoermann (Essen, Germany).

Coating mAbs were coded as INN(sbruck)-hCG-45 (hCG+hCGn-assay), -68 (hCG $\beta$-assay), -106 (hCG $\beta$ cfassay) and INN-hCG-72 (hCG $\alpha$-assay). The detection mAbs (INN-hFSH-158 for the hCG $\alpha$-assay were directed against epitope $\alpha 3$, presumably located on loop 3 of $\mathrm{GPH} \alpha$. To improve assay homogeneity, a single mAb (code: INN-hCG-22) recognizing a broad spectrum of hCG and hCG-like molecules, i.e. hCG, nicked hCG (hCGn), hCG lacking the carboxyl-terminal peptide of the $\beta$-subunit (-CTPhCG), hCG $\beta$, hCG $\beta$ n, -CTPhCG $\beta$ and hCG $\beta c f$, was labeled with isothiocyanatophenylene triamintetraacetic acid-europium (Wallac, Turku, Finland) according to the manufacturer's recommendations [27] and used as a detection reagent in the 3 assays for hCG, hCG $\beta$ and hCG $\beta$ cf, respectively.

The specificities of the applied IFMAs for hCG and hCG variants are summarized in Table 1.

\section{Purification of hCG $\alpha$ from seminal plasma by immunoprecipitation}

Seminal plasma samples from three normozoospermic men were pooled and $1 \mathrm{ml}$ of the pool was diluted 1:2 with modified RIPA buffer (10 mM Tris- $\mathrm{HCl} \mathrm{pH} \mathrm{7.4;}$ $150 \mathrm{mM} \mathrm{NaCl} ; 1 \% \mathrm{NP}-40 ; 0.25 \%$ Na-deoxycholate, complete Mini Protease Inhibitor Cocktail (Roche Diagnostics) and $15 \mu \mathrm{l}$ monoclonal antibody $(4 \mathrm{mg} / \mathrm{ml}$; Code INN-hFSH-132; [18]). The mixture was incubated overnight at $4^{\circ} \mathrm{C}$ on a rotary shaker. A Protein-G agarose resin (Upstate) was added and samples were incubated for further $2 \mathrm{~h}$ at $4^{\circ} \mathrm{C}$. Thereafter, samples were centrifuged, supernatant removed and the Protein-G agarose resin was washed 5 times with modified RIPA buffer. The Protein- $\mathrm{G}$ agarose resin was heated to $95^{\circ} \mathrm{C}$ for 10 min in $50 \mu \mathrm{l}$ modified RIPA buffer and centrifuged at $16,000 \mathrm{~g}$ for $10 \mathrm{~min}$. The pellet was discarded and the $\mathrm{hCG} \alpha$-containing supernatant stored at $-20^{\circ} \mathrm{C}$.

\section{Digestion with glycosidase}

hCG $\alpha$ purified from seminal plasma by IP, as described above (2.4.) and, for comparative purposes, large free hCG $\alpha$ purified by HPLC from supernatant of HEK293 stably transfected with $\beta_{2} \mathrm{AR}$ and specifically stimulated with $10 \mu \mathrm{M}$ isoproterenol [28], as well as the frozen

Table 1 Specificity of IFMAs for hCG and/or hCG-variants

\begin{tabular}{|c|c|c|c|}
\hline Assay type & Assay specificity & $\begin{array}{l}\text { Capture mAb } \\
\text { Epitope localization }\end{array}$ & Detection mAb Epitope localization \\
\hline hCG & $\begin{array}{l}\text { hCG intact } \alpha \beta \text { heterodimer, bioactive; } \\
\text { hCGn nicked } \alpha \beta \text { heterodimer, nicks in the region of aa hCG } \beta 44-48\end{array}$ & $\begin{array}{l}\text { INN-hCG-45 } \\
C_{3} \\
\text { hCG } \beta \text { loop } 2\end{array}$ & $\begin{array}{l}\text { INN-hCG-22 } \\
\beta_{2} \\
\text { hCG } \beta \text { loops 1+3 } \\
\text { aa 20-25+68-77 }\end{array}$ \\
\hline hCG $\beta$ & $\begin{array}{l}\text { hCG } \beta \text { intact non-combined free hCG } \beta \text {-subunit, aa hCG } \beta 1-145 \text {; } \\
\text { hCG } \beta \text { cf core fragment of hCG } \beta \text {; aa hCG } \beta 6-40 \text { linked to hCG } 355-92 \text {; } \\
\text { hCG } \beta \text { n nicked hCG } \beta \text {, nicks in the region of aa hCG } \beta 44-48\end{array}$ & $\begin{array}{l}\text { INN-hCG-68 } \\
\beta_{7} \\
\text { hCG } \beta \text { Cf }\end{array}$ & INN-hCG-22 \\
\hline hCG $\beta c f$ & hCGßcf-only & $\begin{array}{l}\text { INN-hCG-106 } \\
\beta_{11} \\
\text { hCG } \beta \text { cf }\end{array}$ & INN-hCG-22 \\
\hline $\mathrm{hCG} \alpha$ & hCG $\alpha$ intact non-combined free a-subunit of hCG; aa hCG $\alpha 1-92$ & $\begin{array}{l}\text { INN-hCG-72 } \\
\alpha_{6} \\
\text { hCG } 33-42\end{array}$ & $\begin{array}{l}\text { INN-hFSH-158 } \\
\alpha_{5} \\
\text { Loop } 3(\text { Tyr } 65)\end{array}$ \\
\hline
\end{tabular}

Abbreviations and definitions for hCG and hCG-derived molecules as put forward by the IFCC Working Group for Standardization of hCG (Berger et al., 2002) aa ... amino acids 
carrier-free concentrate (FC 862) of the WHO adopted $1^{\text {st }}$ International Reference Preparation for Immunoassay of hCG $\alpha\left(1^{\text {st }}\right.$ IRP hCG $\alpha$ 99/720) were deglycosylated with peptide N-glycanase PNGase F (New England BioLabs). For digestion under non-reducing conditions to remove the glycan at $\mathrm{Asn}^{52}$ [29,30], $15 \mu \mathrm{l}$ samples equivalent to $150 \mathrm{ng}$ hCG $\alpha$ were incubated with $1.5 \mu \mathrm{l}$ $0.5 \mathrm{M}$ sodium phosphate buffer ( $\mathrm{pH}$ 7.5), $1.5 \mu \mathrm{l} \mathrm{NP}-40$ and $1 \mu \mathrm{l}$ Enzyme (PNGase F, $500 \mathrm{U}$ ) for $2 \mathrm{hrs}$ at $37^{\circ} \mathrm{C}$. For digestion under reducing conditions to remove both glycan moieties, samples were incubated with $1.5 \mu \mathrm{l} 10 \times$ denaturing buffer (5\% SDS, $10 \% \beta$-mercaptoethanol) for $10 \min \left(95^{\circ} \mathrm{C}\right)$ and put on ice prior to deglycosylation.

\section{Western Blot}

Samples were diluted with sample buffer to $25 \mu \mathrm{l}$, separated via gel electrophoresis on $4 \%$ stacking and $13 \%$ separating gels and transferred to an Immun-Blot ${ }^{\mathrm{TM}}$ polyvinylidene difluoride (PVDF) membrane (Bio-Rad Laboratories). Membranes were probed with mouse monoclonal antibody INN-hFSH-132 at a dilution of 1:2,000 for blots under non-reducing conditions and rabbit hCG $\alpha$ antiserum at a dilution of 1:10,000 for reduced proteins, respectively. Detection was performed with HRP-conjugated secondary antibodies (Promega), chemoluminescent substrate (Amersham ECLTM Western Blotting Analysis System, GE Healthcare) and exposure to ECL Hyperfilm (GE Healthcare).

\section{Verification of $\mathrm{hCG} \alpha$ by mass spectrometry}

hCG $\alpha$ purified from seminal plasma by IP, as described above (2.4.), was analyzed by SDS-PAGE, and the protein band at $24 \mathrm{kDa}$ was excised from the gel and digested with endoproteinase Lys-C [EC 3.4.21.50] (Sigma-Aldrich, $1 / 20 \mathrm{w} / \mathrm{w}$ ) in $100 \mathrm{mM} \mathrm{H}_{4} \mathrm{HCO}_{3}$ buffer $(\mathrm{pH}=8.0)$ for 2 hours at $37^{\circ} \mathrm{C}$. The digest was analyzed using nano-HPLC consisting of an UltiMate 3000 System (Dionex Corporation) connected online to a linear iontrap mass spectrometer ThermoElectron Finnigan LTQ) equipped with a nanospray ionization source. The nanospray voltage was set at $1.6 \mathrm{kV}$, the heated capillary was held at $200^{\circ} \mathrm{C} . \mathrm{MS} / \mathrm{MS}$, and spectra were searched against a human protein database using SEQUEST (LCQ BioWorks; ThermoFinnigan).

\section{Statistical analyses}

Results are expressed as mean values \pm SEM. Statistical differences among groups were calculated by unpaired Student's t-test and considered significant at $P<0.05$.

\section{Results}

\section{Characterization of patients: Serum hormone levels}

Serum levels of TT, FSH, LH and hPRL were analyzed in 21 patients with abnormal semen analyses $($ OAT $\mathrm{n}=$
5 , asthenozoospermia $\mathrm{n}=2$, teratozoospermia $\mathrm{n}=1$, oligozoospermia $\mathrm{n}=1$, cryptozoospermia $\mathrm{n}=8$, azoospermia $\mathrm{n}=4$ ) and compared with 6 control subjects with normal semen analyses (Figure 2A). Patients with pathologic semen analysis findings showed no significant differences in TT and LH serum levels, while hPRL levels were significantly elevated $(6.4 \pm 0.7$ vs. $4.5 \pm 0.3 \mathrm{ng} / \mathrm{ml}$; $P=0.02$ ). Mean serum FSH levels were significantly increased in the abnormal group compared with controls $(9.7 \pm 1.4$ vs. $3.1 \pm 0.1 \mathrm{mIU} / \mathrm{ml} ; P=0.0001)$, and elevation of FSH levels (Figure $2 \mathrm{~B}$ ) was more pronounced in patients diagnosed with cryptozoospermia $(12.4 \pm 2.5 \mathrm{mIU} / \mathrm{ml}, P=0.003)$ or azoospermia $(12.5 \pm$ $3.8 \mathrm{mIU} / \mathrm{ml}, P=0.04)$ than those diagnosed with OAT $(6.6 \pm 1.5 \mathrm{mIU} / \mathrm{ml}, P=0.04)$.
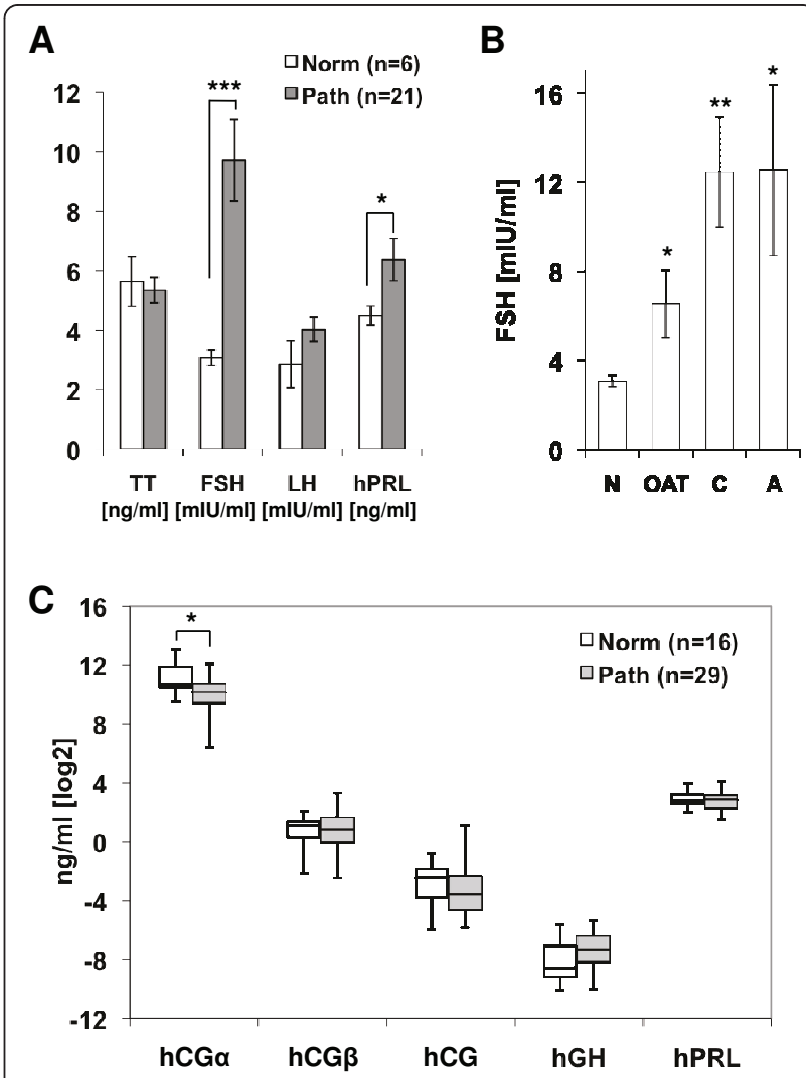

Figure 2 Serum and seminal plasma hormone levels in men with impaired semen quality. (A) Serum T, FSH, LH and hPRL levels in men with pathologic semen analyses findings (Path) and normozoospermic controls (Norm). Men with impaired semen quality showed significantly elevated FSH and hPRL levels. (B) Serum FSH levels were significantly higher in men with oligoasthenoterato- (OAT), crypto- (C) or azoospermia. (C) Hormone variants analyzed in seminal plasma revealed significantly lower hCG $\alpha$ levels in patients with abnormal semen analyses compared with controls. Statistical significance was determined by unpaired Student's t-test ( $\left.P<0.05 ;{ }^{*} P<0.001\right)$. 


\section{Decreased hCG $\alpha$ levels in seminal plasma of men with abnormal semen analysis results}

Hormone and hormone derivative levels were determined by respective IFMAs in seminal plasma specimens from 29 patients with abnormal semen analyses and compared with samples from 16 control subjects with normal semen analyses (Table 2). hPL and hCG $\beta$ cf levels were similarly low in both groups, with several samples below the detection limit preventing statistical evaluation. hCG $\beta$, holo-hCG, hGH and hPRL levels were not significantly different in the two cohorts (Figure 2B). However, free hCG $\alpha$ levels were significantly lower in patients with pathologic semen analysis findings (1346 \pm 191 vs. $2753 \pm 533 \mathrm{ng} / \mathrm{ml} ; P=0.022)$.

\section{Decreased seminal plasma holo-hCG levels in patients with decreased sperm count}

In patients with impaired semen quality, the highest variability of all analyzed hormones was observed for holo-hCG (0.279 $\pm 0.101 \mathrm{ng} / \mathrm{ml}$, Table 2). Patients with astheno-, terato- or asthenoteratozoospermia had higher, but statistically insignificant, hCG seminal plasma levels. On the other hand, patients diagnosed with reduced sperm counts (oligo-, oligoasthenoterato-, crypto- or azoospermia; $n=23$ ) had significantly reduced $\mathrm{hCG}$ levels compared with normozoospermic men $(0.097 \pm$ 0.022 vs. $0.203 \pm 0.040 \mathrm{ng} / \mathrm{ml}, P=0.028$, Figure $3 \mathrm{~A})$. While hCG $\beta$ levels were not significantly different $(1.80$ \pm 0.27 vs. $2.05 \pm 0.29 \mathrm{ng} / \mathrm{ml}, P=0.55$, Figure $3 \mathrm{~B})$, mean hCG $\alpha$ levels were significantly reduced in patients with reduced sperm counts $(1237 \pm 197$ vs. $2753 \pm 533 \mathrm{ng} /$ $\mathrm{ml}, P=0.015$, Figure $3 \mathrm{C}$ ). Given the fact that hCG as well as hCG $\alpha$ were similarily reduced by approximately $50-60 \%$ in both cohorts, the ratio of $\mathrm{hCG} \alpha / \mathrm{hCG}$ was analyzed and found to be comparable (normozoospermia: $25.7 \pm 6.1 \times 10^{3}$, reduced sperm count: $17.9 \pm 3.2$ $\times 10^{3}$, Figure 3D). Patients with astheno-, terato- or asthenoteratozoospermia had a strongly reduced hCG $/$ hCG ratio $\left(2.6 \pm 0.5 \times 10^{3}\right.$, Figure 3D).

\section{Genuine large $\mathrm{hCG} \alpha$ in seminal plasma}

Given the high free hCG $\alpha$ levels in seminal fluid compared with serum (approximately 10,000-fold higher, as described previously [13]) and the decreased levels in seminal plasma of patients with poor semen analysis, the hormone derivative from these patients was purified and investigated in more detail.

Under non-reducing conditions, hCG $\alpha$ dissociated from pregnancy-derived holo-hCG migrated as an approximately $22 \mathrm{kDa}$ band (Figure $4 \mathrm{~A}$ ). Large free hCG $\alpha$, which is unable to associate with $\beta$-subunits due to larger N-linked sugar chains [31], had an apparent molecular mass $\left(\mathrm{M}_{\mathrm{r} \text {,app }}\right)$ of $24 \mathrm{kDa}$. hCG $\alpha$ isolated form seminal plasma migrated comparable with HEK293- derived large free hCG $\alpha$. After digestion of the glycan at $\mathrm{Asn}^{52}$, the dissociated standard and HEK293-derived large free hCG $\alpha$ showed identical $\mathrm{M}_{\mathrm{r} \text {,app }}$ of $18 \mathrm{kDa}$, while protein isolated from seminal fluid migrated as a diffuse band of approximately 19 - $20 \mathrm{kDa}$ (Figure 4A). When both glycan moieties were removed, all three $\mathrm{hCG} \alpha$ variants tested resulted a $15 \mathrm{kDa}$ deglycosylated protein.

The biochemical identity of hCG $\alpha$ purified from seminal fluid was verify by nano-HPLC MS/MS analysis after digestion with endoproteinase Lys-C (Table 3).

\section{Discussion}

Protein and glycoprotein hormone-like substances have been described previously in human seminal fluid, but the lack of antibodies and consequent sandwich assays with clearly defined glycoprotein hormone variant recognition patterns meant that a general variant profile of these markers and their relationship to fertility disturbances could not be accomplished. We analyzed the profile of endocrine parameters in patients with abnormal semen analysis findings in comparison to normozoospermic men to elucidate a putative pathophysiological role of glycoprotein hormone variants in spermatogenesis disorders.

To characterize the patient cohort serum levels of TT, FSH, LH and hPRL were analyzed. In accordance with previous reports [32], significantly higher serum hPRL levels were found in men with abnormal semen analysis, but still within the normal range, indicating that the patients did not suffer from hyperprolactinemia. Mean serum FSH levels were above the normal reference range $(1.3-8.4 \mathrm{mIU} / \mathrm{ml}[33])$ in patients with abnormal semen analysis and highest in patients with cryptozoospermia and azoospermia, reflecting a decline in function of seminiferous tubules [34]. High heterogeneity of FSH levels indicated that men with both obstructive and non-obstructive azoospermia were included in the study cohort.

In seminal plasma levels of hCG $\alpha$ were found to be significantly lower in patients with abnormal semen analyses. Similarly, in patients with reduced sperm count, intact hCG levels were significantly lower. In these patients, the hCG $\alpha / \mathrm{hCG}$ ratio was comparable with normozoospermic men, indicating co-secretion of free hCG $\alpha$ and hCG $\alpha$ associated with hCG $\beta$. Compared with hCG, free hCG $\beta$ is present in seminal plasma in an approximately 10-fold, and free hCG $\alpha$ in an approximately 10,000-fold excess. Thus, free hCG $\alpha$ appeared as large subunit, distinct from the $\alpha$ subunit present in hCG [31] and unable to associate with the available $\beta$ subunit. Non-associable and associated hCG $\alpha$ seem to be secreted at a constant ratio of approximately $10,000: 1$, the latter being the rate limiting subunit of 
Table 2 Hormone and hormone derivative levels $[\mathrm{ng} / \mathrm{ml}]$ in seminal plasma

\begin{tabular}{|c|c|c|c|c|c|c|c|c|c|c|c|c|c|c|c|c|c|c|}
\hline \multirow[t]{2}{*}{ Diagnosis } & \multicolumn{2}{|c|}{ Age [years] } & \multicolumn{2}{|c|}{ Sperm counts } & \multirow{2}{*}{$\begin{array}{c}\mathrm{hCG} \alpha \\
\text { range }\end{array}$} & \multirow[b]{2}{*}{ mean } & \multirow{2}{*}{$\begin{array}{c}\mathrm{hCG} \beta \\
\text { range }\end{array}$} & \multirow[b]{2}{*}{ mean } & \multirow{2}{*}{$\begin{array}{r}\text { hCG } \beta \text { cf } \\
\text { range }\end{array}$} & \multirow[b]{2}{*}{ mean } & \multirow{2}{*}{$\begin{array}{c}\text { hCG } \\
\text { range }\end{array}$} & \multicolumn{3}{|c|}{ hGH } & \multicolumn{2}{|l|}{$\mathrm{hPL}$} & \multicolumn{2}{|l|}{ hPRL } \\
\hline & range & mean & range & mean & & & & & & & & mean & range & mean & range & mean & range & mean \\
\hline$N(n=16)$ & $31-57$ & $\begin{array}{c}37.1 \pm \\
1.7\end{array}$ & $\begin{array}{l}25.0- \\
87.5\end{array}$ & $\begin{array}{c}53.7 \pm \\
5.1\end{array}$ & $\begin{array}{l}726- \\
8754\end{array}$ & $\begin{array}{c}2753 \pm \\
533\end{array}$ & $\begin{array}{l}0.23- \\
4.16\end{array}$ & $\begin{array}{c}2.05 \pm \\
0.29\end{array}$ & $\begin{array}{l}<0.005- \\
0.010\end{array}$ & $\begin{array}{c}0.007 \pm \\
0.001\end{array}$ & $\begin{array}{l}0.016- \\
0.578\end{array}$ & $\begin{array}{l}0.203 \pm \\
0.040\end{array}$ & $\begin{array}{l}0.004- \\
0.090\end{array}$ & $\begin{array}{l}0.023 \pm \\
0.006\end{array}$ & $\begin{array}{c}<0.005- \\
0.738\end{array}$ & $\begin{array}{l}0.095 \pm \\
0.072\end{array}$ & $\begin{array}{c}4.00 \pm \\
16.11\end{array}$ & $\begin{array}{c}7.82 \pm \\
0.86\end{array}$ \\
\hline $\begin{array}{c}\text { Path }(\mathrm{n}= \\
\text { 29) }\end{array}$ & $21-48$ & $\begin{array}{l}34.1 \pm \\
1.5\end{array}$ & $0-109.9$ & n.d. & $\begin{array}{c}86- \\
4400\end{array}$ & $\begin{array}{c}1346 \pm \\
191\end{array}$ & $\begin{array}{l}0.18- \\
10.00\end{array}$ & $\begin{array}{c}2.22 \pm \\
0.38\end{array}$ & $\begin{array}{l}<0.005- \\
0.140\end{array}$ & n.d. & $\begin{array}{l}<0.02- \\
2.260\end{array}$ & $\begin{array}{c}0.279 \pm \\
0.101\end{array}$ & $\begin{array}{l}<0.005- \\
0.086\end{array}$ & $\begin{array}{l}0.028 \pm \\
0.005\end{array}$ & $\begin{array}{c}<0.005- \\
1.760\end{array}$ & n.d. & $\begin{array}{l}2.92- \\
17.57\end{array}$ & $\begin{array}{c}7.54 \pm \\
0.78\end{array}$ \\
\hline AS $(n=3)$ & $25-42$ & $\begin{array}{c}34.0 \pm \\
4.9\end{array}$ & $\begin{array}{l}35.6- \\
109.9\end{array}$ & $\begin{array}{c}77.2 \pm \\
21.9\end{array}$ & $\begin{array}{l}110- \\
1500\end{array}$ & $\begin{array}{c}820 \pm \\
402\end{array}$ & $\begin{array}{l}0.36- \\
10.0\end{array}$ & $\begin{array}{c}5.29 \pm \\
2.78\end{array}$ & $\begin{array}{c}<0.05- \\
0.14\end{array}$ & n.d. & $\begin{array}{l}0.060- \\
2.260\end{array}$ & $\begin{array}{c}0.840 \pm \\
0.711\end{array}$ & $\begin{array}{c}<0.005- \\
0.030\end{array}$ & n.d. & $\begin{array}{c}0.016- \\
1.760\end{array}$ & $\begin{array}{l}0.629 \pm \\
0.566\end{array}$ & n.t./7.50 & n.d. \\
\hline $\mathrm{T}(\mathrm{n}=1)$ & 42 & n.d. & 109.3 & n.d. & 2500 & n.d. & 2.8 & n.d. & $<0.005$ & n.d. & 0.82 & n.d. & 0.007 & n.d. & 0.21 & n.d. & n.d. & n.d. \\
\hline $\begin{array}{c}\operatorname{AST}(n= \\
2)\end{array}$ & 30 & n.d. & $\begin{array}{l}\text { n.d/ } \\
19.5\end{array}$ & n.d. & $\begin{array}{l}1100- \\
4400\end{array}$ & n.d. & $\begin{array}{l}2.10- \\
2.16\end{array}$ & n.d. & $\begin{array}{l}<0.005- \\
0.024\end{array}$ & n.d. & $0.5-1.3$ & n.d. & n.t./0.006 & n.d. & $\begin{array}{c}<0.005- \\
0.160\end{array}$ & n.d. & n.t./7.38 & n.d. \\
\hline$O(n=2)$ & $23-45$ & n.d. & $\begin{array}{l}13.1- \\
16.1\end{array}$ & n.d. & $\begin{array}{l}669- \\
1500\end{array}$ & n.d. & $\begin{array}{l}0.40- \\
1.02\end{array}$ & n.d. & $\begin{array}{c}<0.005 / \mathrm{n} \\
\mathrm{d} .\end{array}$ & n.d. & $\begin{array}{l}<0.02- \\
0.041\end{array}$ & n.d. & $\begin{array}{l}<0.005- \\
0.050\end{array}$ & n.d. & 0.007 & n.d. & n.t./3.87 & n.d. \\
\hline $\begin{array}{c}\text { OAT }(n= \\
7)\end{array}$ & $22-36$ & $\begin{array}{c}29.0 \pm \\
1.9\end{array}$ & $0.6-6.2$ & $\begin{array}{c}3.7 \pm \\
0.8\end{array}$ & $\begin{array}{l}610- \\
1938\end{array}$ & $\begin{array}{l}1107 \pm \\
176\end{array}$ & $\begin{array}{l}0.56- \\
2.00\end{array}$ & $\begin{array}{c}1.38 \pm \\
0.24\end{array}$ & $<0.005$ & $<0.005$ & $\begin{array}{l}<0.02- \\
0.234\end{array}$ & $\begin{array}{l}0.102 \pm \\
0.037\end{array}$ & $\begin{array}{c}<0.005- \\
0.049\end{array}$ & $\begin{array}{l}0.029 \pm \\
0.007\end{array}$ & $<0.02$ & $<0.02$ & $3.34-8.09$ & $\begin{array}{c}5.44 \pm \\
1.16\end{array}$ \\
\hline$C(n=8)$ & $21-45$ & $\begin{array}{c}34.5 \pm \\
2.7\end{array}$ & $\begin{array}{l}<0.3- \\
0.3\end{array}$ & n.d. & $\begin{array}{l}192- \\
3661\end{array}$ & $\begin{array}{c}1522 \pm \\
428\end{array}$ & $\begin{array}{l}0.70- \\
3.39\end{array}$ & $\begin{array}{c}2.04 \pm \\
0.41\end{array}$ & $<0.005$ & $<0.005$ & $\begin{array}{l}<0.02- \\
0.420\end{array}$ & $\begin{array}{l}0.122 \pm \\
0.016\end{array}$ & $\begin{array}{l}<0.005- \\
0.086\end{array}$ & $\begin{array}{c}0.039 \pm \\
0.012\end{array}$ & $<0.02$ & $<0.02$ & $\begin{array}{l}2.92- \\
17.57\end{array}$ & $\begin{array}{c}8.85 \pm \\
1.73\end{array}$ \\
\hline$A(n=6)$ & $31-48$ & $\begin{array}{c}39.8 \pm \\
3.3\end{array}$ & 0 & 0 & $\begin{array}{c}86- \\
2630\end{array}$ & $\begin{array}{c}1108 \pm \\
394\end{array}$ & $\begin{array}{l}0.18- \\
5.21\end{array}$ & $\begin{array}{c}2.35 \pm \\
0.82\end{array}$ & $<0.005$ & $<0.005$ & $\begin{array}{c}<0.02- \\
0.120\end{array}$ & $\begin{array}{c}0.066 \pm \\
0.018\end{array}$ & $\begin{array}{l}0.003- \\
0.037\end{array}$ & $\begin{array}{c}0.016 \pm \\
0.006\end{array}$ & $<0.02$ & $<0.02$ & $7.00-8.86$ & $\begin{array}{c}7.88 \pm \\
0.34\end{array}$ \\
\hline
\end{tabular}

Patients were grouped according to spermiogram (WHO 1995): normozoospermia (N), abnormal semen analysis results (Path), asthenozoospermia (AS), teratozoospermia (T), asthenoteratozoospermia (AST), oligozoospermia (O), oligoastheoteratozoospermia (OAT), cryptozoospermia (C), azoospermia 

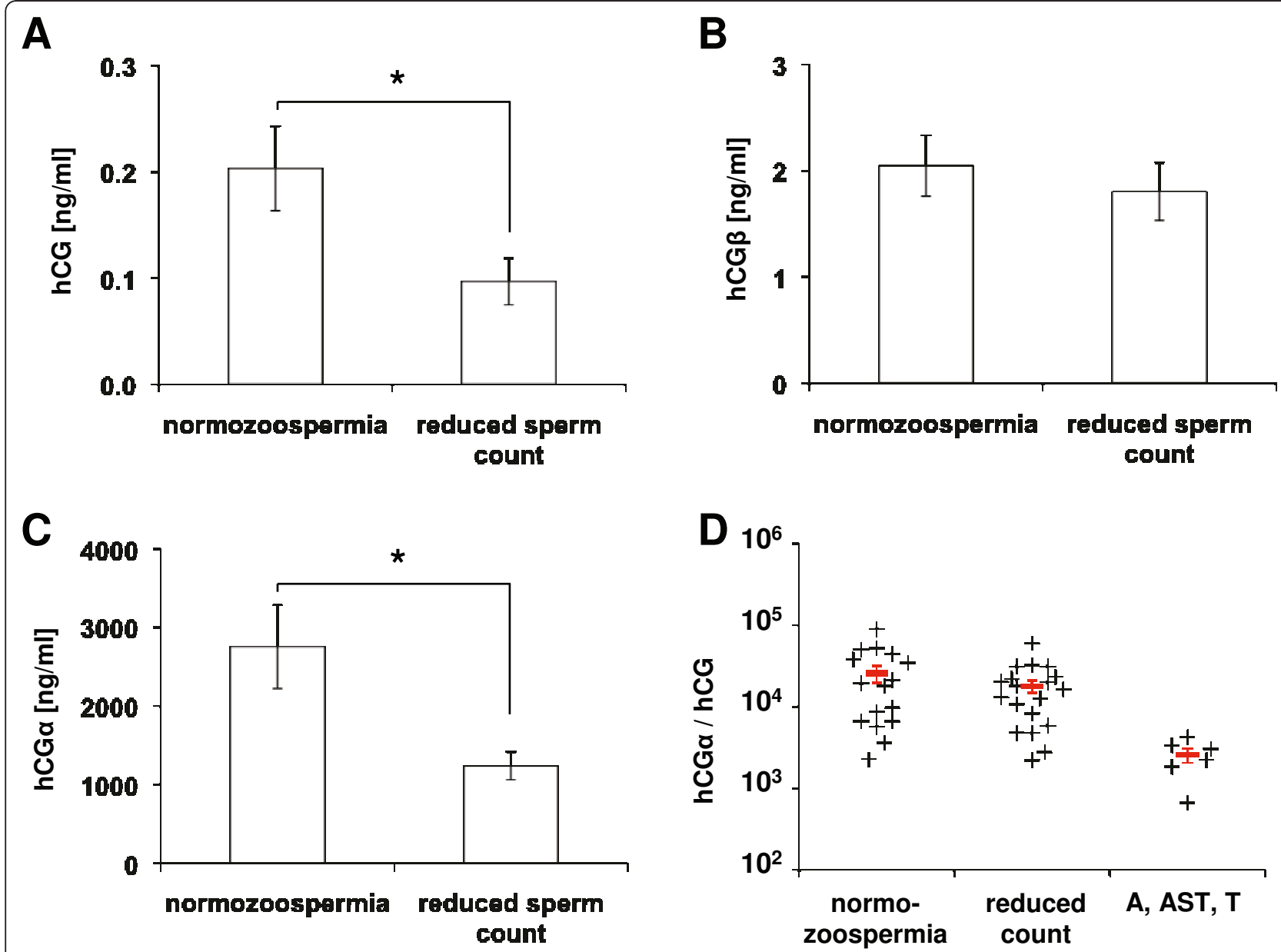

Figure 3 Reduced hCG and free hCG $\alpha$ seminal plasma levels in men with reduced sperm count. (A) Patients with reduced sperm count $(n=23)$ showed significantly lower free holo-hCG levels compared with normozoospermic controls $(n=16)$, while (B) free hCG $\beta$ levels were not affected. (C) Similar to holo-hCG, free hCG $\alpha$ levels were significantly lower in men with reduced sperm count, resulting in (D) hCG $\alpha / h C G$ ratios comparable to normozoospermic men, while men with asthenozoospermia, teratozoospermia or asthenoteratozoospermia (AS, T, AST; $n=$ 6) showed reduced $\mathrm{hCG} \alpha / \mathrm{hCG}$ ratios. Red bars indicated mean \pm SEM. (A-C) Statistical significance was calculated by Student's t-test (* $P<0.05$ ).

holo-hCG association. On the other hand, the hCG $\alpha$ / hCG ratio was reduced in patients with astheno-, teratoor asthenoteratozoospermia, although the limited number of patients in this cohort require confirmation of these alterations by further research. Other hormone variants were not significantly different in the cohorts tested and generally expressed at low levels.

The pathophysiological role of reduced hCG $\alpha$ and hCG levels is uncertain. We previously showed hCG $\beta$ expression in the testis in peritubular and presumably Leydig cells [13]. Due to its structural homology to LH, hCG is able to stimulate $\mathrm{T}$ production by Leydig cells. Thus, it could be hypothesized that hCG expression in the testis serves as a local backup system to sustain basal $\mathrm{T}$ secretion. However, hCG levels in seminal plasma were very low $(0.016-0.578 \mathrm{ng} / \mathrm{ml}$ in normozoospermic men). During pregnancy, the serum ratios of
hCG to the free $\alpha$ and $\beta$ subunits is usually in the range in 100:1, while in seminal plasma, hCG $\alpha$ is found in 10,000 -fold excess $(726-8754 \mathrm{ng} / \mathrm{ml}$ in normozoospermic men) of the holo-hormone.

The molecular function of the free hCG $\alpha$ is still unresolved, and no receptors for the free subunit have yet been described. Free hCG $\alpha$ has been reported to stimulate endometrial stromal cell differentiation synergistically with progesterone [35]. Antisense hCG $\alpha$ RNA reduced the tumorigenic potential of lung cancer cells [36] and hCGa inhibited growth of prostatic stromal cells [37]. In the male reproductive tract, several sources of free hCGa have been described, in particular the prostate [37-39]. Moreover, significant amounts of hCG $\alpha$ have been detected in seminal vesicle fluid, and minor concentrations in the testis $[13,40]$. Herein, we demonstrate that hCG $\alpha$ purified from seminal plasma 


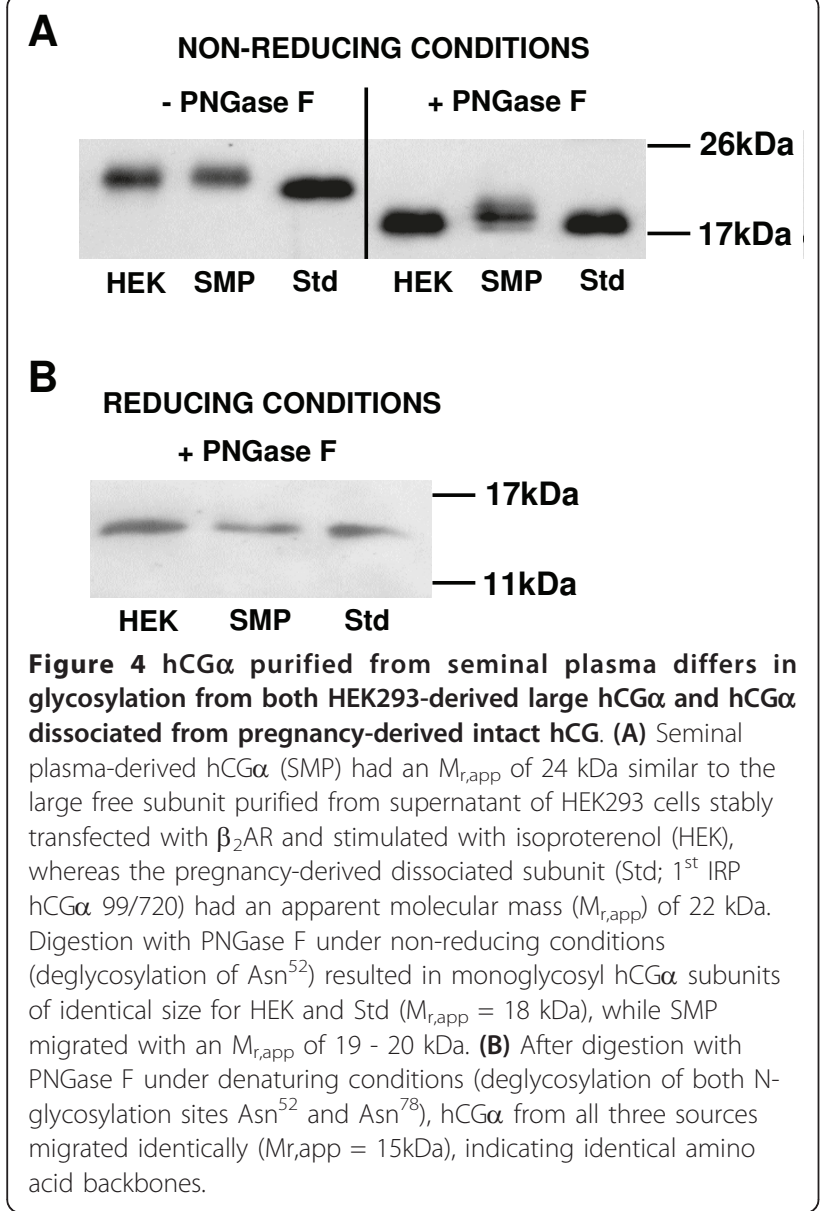

had the $\mathrm{M}_{\mathrm{r} \text {,app }}$ of large free $\mathrm{hCG} \alpha$, which is incapable of associating with $\beta$-subunits due to larger $\mathrm{N}$-linked sugar chains [31]. Interestingly, the large free $\alpha$ subunit isolated from seminal fluid showed a different glycosylation pattern than large hCG $\alpha$ produced from HEK cells stably transfected with $\beta_{2} \mathrm{AR}$ and stimulated with isoproterenol [28]. While the latter appeared to be more highly glycosylated at $\mathrm{Asn}^{52}$, seminal plasma-derived hCGa appeared to be more highly glycosylated at $\mathrm{Asn}^{78}$. This might reflect distinct molecular functions of large free hCG $\alpha$ variants from different sources due to alternative glycosylation. After total deglycosylation, hCGa derived

Table $3 \mathrm{MS} / \mathrm{MS}$ analysis of free $\mathrm{hCG} \alpha$ isolated from seminal plasma

\begin{tabular}{lcccc}
\hline Sequence & MH+ & \% Mass & Position & \% AA \\
\hline TMLVQK & 719.41 & 5.51 & $70-75$ & 5.17 \\
SYNRVTVMGGFK & 1358.41 & 10.40 & $88-99$ & 10.34 \\
Total & 2059.08 & 15.76 & 18 & 15.52 \\
\hline
\end{tabular}

The identified amino acid (AA) sequences after Lys-C digestion, the 1+ charge state $[\mathrm{MH}+]$ of the $\mathrm{hCG} \alpha$ protein fragments, the percent mass, the positions of amino acid residues, and percentage of the amino acid sequence obtained by database search using SEQUEST are shown. from seminal plasma, HEK cells and dissociated from the heterodimeric $\mathrm{hCG}$ showed identical $\mathrm{M}_{\mathrm{r} \text {,app }}$, indicating identical amino acid backbone and genuineness of large free hCG $\alpha$ in seminal plasma as shown by nanospray MS. Thus, due to its unique gylcosylation pattern, free hCG $\alpha$ purified from seminal plasma, where it is normally present in high concentrations and is reduced in men with abnormal semen analysis, represents a promising variant to investigate the unresolved molecular function of the free subunit.

\section{Conclusions}

Levels of free hCG $\alpha$, by far the most abundant hCG variant in seminal plasma, were significantly reduced in men with abnormal semen analyses. Additionally, in men with reduced sperm counts, holo-hCG levels were accordingly lower, indicating a pathophysiological relevance of these hormone variants in spermatogenesis. hCG $\alpha$ in seminal plasma was identified as being a highly glycosylated large free subunit with a unique glycosylation pattern. Alternative glycosylation clearly might modify the function of the hormone subunit, thus free large hCG $\alpha$ purified from seminal plasma represents a promising molecular entity to further investigate the physiological role of free hCG $\alpha$ in spermatogenesis.

\section{Acknowledgements}

Supernatant of HEK293 stably transfected with $\beta_{2}$ AR was kindly provided by Tommaso Costa (Department of Pharmacology, Istituto Superiore di Sanità, Rome, Italy). The manuscript was edited by M. K. Occhipinti-Bender.

\section{Author details}

${ }^{1}$ Institute for Biomedical Aging Research, Austrian Academy of Sciences, Rennweg 10, 6020 Innsbruck, Austria. ${ }^{2}$ Department of Dermatology, University of Erlangen-Nuremberg, Hartmannstraße 14, 91052 Erlangen, Germany. ${ }^{3}$ Division of Clinical Biochemistry and Protein Micro-Analysis Facility, Medical University Innsbruck, Fritz-Pregl-Str. 3, 6020 Innsbruck, Austria. ${ }^{4}$ Department of Urology and Ludwig Boltzmann Institute for Urology and Andrology, Hospital Hietzing, Wolkersbergenstraße 1, 1130 Vienna, Austria.

\section{Authors' contributions}

CZ performed the statistical analysis and drafted the manuscript. RG carried out the immunoassays. MG and EP participated in the design of the study and determined serum hormone levels and sperm parameters. $\mathrm{HL}$ performed mass spectrometry. PB conceived of the study, participated in its design and coordination and helped to draft the manuscript. All authors read and approved the final manuscript.

\section{Competing interests}

The authors declare that they have no competing interests.

Received: 15 July 2011 Accepted: 12 August 2011

Published: 12 August 2011

\section{References}

1. Toulis KA, lliadou PK, Venetis CA, Tsametis C, Tarlatzis BC, Papadimas I, Goulis DG: Inhibin B and anti-Mullerian hormone as markers of persistent spermatogenesis in men with non-obstructive azoospermia: a meta-analysis of diagnostic accuracy studies. Hum Reprod Update 16(6):713-724. 
2. Asch RH, Fernandez EO, Siler-Khodr TM, Pauerstein CJ: Peptide and steroid hormone concentrations in human seminal plasma. Int J Fertil 1984, 29(1):25-32

3. Asch RH, Fernandez EO, Siler-Khodr TM, Pauerstein CJ: Presence of a human chorionic gonadotropin-like substance in human sperm. Am J Obstet Gynecol 1979, 135(8):1041-1047.

4. Brotherton J: Human chorionic gonadotrophin in human seminal plasma as shown with assays using monoclonal antibodies. Andrologia 1989, 21(5):407-415.

5. de Medeiros SF, Amato F, Bacich D, Wang L, Matthews CD, Norman RJ: Distribution of the beta-core human chorionic gonadotrophin fragment in human body fluids. J Endocrinol 1992, 135(1):175-188.

6. Saito S, Kumamoto $Y$, Ito N, Kurohata T: Human chorionic gonadotropin beta-subunit in human semen. Arch Androl 1988, 20(1):87-99.

7. Chan SY, Chan PH, Tang LC, Ho PC, Tang GW: Seminal plasma betahuman chorionic gonadotropin (beta-HCG): relationships with seminal characteristics and spermatozoal fertilizing capacity. Andrologia 1986, 18(1):50-55.

8. Caroppo E, Niederberger C, lacovazzi PA, Correale M, Palagiano A, D'Amato G: Human chorionic gonadotropin free beta-subunit in the human seminal plasma: a new marker for spermatogenesis? Eur J Obstet Gynecol Reprod Biol 2003, 106(2):165-169.

9. Lee JN, Lian JD, Lee JH, Chard T: Placental proteins (human chorionic gonadotropin, human placental lactogen, pregnancy-specific beta 1glycoprotein, and placental protein 5) in seminal plasma of normal men and patients with infertility. Fertil Steril 1983, 39(5):704-706.

10. Sturgeon CM, McAllister EJ: Analysis of hCG: clinical applications and assay requirements. Ann Clin Biochem 1998, 35(Pt 4):460-491.

11. Berger $P$, Sturgeon C, Bidart JM, Paus E, Gerth R, Niang M, Bristow A, Birken S, Stenman UH: The ISOBM TD-7 Workshop on hCG and related molecules. Towards user-oriented standardization of pregnancy and tumor diagnosis: assignment of epitopes to the three-dimensional structure of diagnostically and commercially relevant monoclonal antibodies directed against human chorionic gonadotropin and derivatives. Tumour Biol 2002, 23(1):1-38.

12. Birken $S$, Berger $P$, Bidart JM, Weber M, Bristow A, Norman R, Sturgeon $C$, Stenman UH: Preparation and characterization of new WHO reference reagents for human chorionic gonadotropin and metabolites. Clin Chem 2003, 49(1):144-154.

13. Berger P, Gruschwitz M, Spoettl G, Dirnhofer S, Madersbacher S, Gerth R, Merz WE, Plas E, Sampson N: Human chorionic gonadotropin (hCG) in the male reproductive tract. Mol Cell Endocrinol 2007, 260-262:190-196.

14. Kobata A, Takeuchi M: Structure, pathology and function of the N-linked sugar chains of human chorionic gonadotropin. Biochim Biophys Acta 1999, 1455(2-3):315-326.

15. WHO: Laboratory manual for the examination of human semen and semen-cervical mucus interaction. Cambridge: Cambridge University Press; 1995.

16. Bronson R, Cooper G, Hjort $T$, Ing R, Jones WR, Wang SX, Mathur S, Williamson HO, Rust PF, Fudenberg HH, et al: Anti-sperm antibodies, detected by agglutination, immobilization, microcytotoxicity and immunobead-binding assays. J Reprod Immunol 1985, 8(4):279-299.

17. Berger P, Panmoung W, Khaschabi D, Mayregger B, Wick G: Antigenic features of human follicle stimulating hormone delineated by monoclonal antibodies and construction of an immunoradiomometric assay. Endocrinology 1988, 123(5):2351-2359.

18. Berger P, Klieber R, Panmoung W, Madersbacher S, Wolf H, Wick G: Monoclonal antibodies against the free subunits of human chorionic gonadotrophin. J Endocrinol 1990, 125(2):301-309.

19. Schwarzler $P$, Untergasser $G$, Hermann M, Dirnhofer S, Abendstein B, Berger P: Prolactin gene expression and prolactin protein in premenopausal and postmenopausal human ovaries. Fertil Steril 1997, 68(4):696-701.

20. Staindl B, Berger P, Kofler R, Wick G: Monoclonal antibodies against human, bovine and rat prolactin: epitope mapping of human prolactin and development of a two-site immunoradiometric assay. J Endocrinol 1987, 114(2):311-318.

21. Madersbacher S, Kratzik C, Gerth R, Dirnhofer S, Berger P: Human chorionic gonadotropin ( $\mathrm{hCG}$ ) and its free subunits in hydrocele fluids and neoplastic tissue of testicular cancer patients: insights into the in vivo hCG-secretion pattern. Cancer Res 1994, 54(19):5096-5100.
22. Madersbacher S, Stulnig T, Huber LA, Schonitzer D, Dirnhofer S, Wick G, Berger $P$ : Serum glycoprotein hormones and their free alpha-subunit in a healthy elderly population selected according to the SENIEUR protocol. Analyses with ultrasensitive time resolved fluoroimmunoassays. Mech Ageing Dev 1993, 71(3):223-233.

23. Dirnhofer S, Lechner O, Madersbacher S, Klieber R, de Leeuw R, Wick G, Berger $P$ : Free alpha subunit of human chorionic gonadotrophin: molecular basis of immunologically and biologically active domains. $J$ Endocrinol 1994, 140(1):145-154

24. Schwarz S, Berger P, Wick G: The antigenic surface of human chorionic gonadotropin as mapped by murine monoclonal antibodies. Endocrinology 1986, 118(1):189-197.

25. Dirnhofer S, Madersbacher S, Bidart JM, Ten Kortenaar PB, Spottl G, Mann K, Wick G, Berger P: The molecular basis for epitopes on the free betasubunit of human chorionic gonadotrophin (hCG), its carboxyl-terminal peptide and the hCG beta-core fragment. J Endocrinol 1994 141(1):153-162.

26. Madersbacher S, Klieber R, Mann K, Marth C, Tabarelli M, Wick G, Berger P: Free alpha-subunit, free beta-subunit of human chorionic gonadotropin (hCG), and intact hCG in sera of healthy individuals and testicular cancer patients. Clin Chem 1992, 38(3):370-376.

27. Madersbacher S, Berger P: Antibodies and immunoassays. Methods 2000, 21(1):41-50.

28. Casella I, Lindner H, Zenzmaier C, Riitano D, Berger P, Costa T: Nongonadotropin-releasing hormone-mediated transcription and secretion of large human glycoprotein hormone alpha-subunit in human embryonic kidney-293 cells. Endocrinology 2008, 149(3):1144-1154.

29. Van Zuylen CW, De Beer T, Rademaker GJ, Haverkamp J, Thomas-Oates JE, Hard K, Kamerling JP, Vliegenthart JF: Site-specific and complete enzymic deglycosylation of the native human chorionic gonadotropin alphasubunit. Eur J Biochem 1995, 231(3):754-760.

30. Erbel PJ, Haseley SR, Kamerling JP, Vliegenthart JF: Studies on the relevance of the glycan at Asn-52 of the alpha-subunit of human chorionic gonadotropin in the alphabeta dimer. Biochem J 2002, 364(Pt 2):485-495.

31. Blithe $\mathrm{DL}$ : N-linked oligosaccharides on free alpha interfere with its ability to combine with human chorionic gonadotropin-beta subunit. $J$ Biol Chem 1990, 265(35):21951-21956.

32. Merino G, Carranza-Lira S, Martinez-Chequer JC, Barahona E, Moran C, Bermudez JA: Hyperprolactinemia in men with asthenozoospermia, oligozoospermia, or azoospermia. Arch Androl 1997, 38(3):201-206.

33. Sikaris K, McLachlan Rl, Kazlauskas R, de Kretser D, Holden CA, Handelsman DJ: Reproductive hormone reference intervals for healthy fertile young men: evaluation of automated platform assays. J Clin Endocrinol Metab 2005, 90(11):5928-5936.

34. Sokol RZ: Endocrinology of male infertility: evaluation and treatment. Semin Reprod Med 2009, 27(2):149-158.

35. Moy E, Kimzey LM, Nelson LM, Blithe DL: Glycoprotein hormone alphasubunit functions synergistically with progesterone to stimulate differentiation of cultured human endometrial stromal cells to decidualized cells: a novel role for free alpha-subunit in reproduction. Endocrinology 1996, 137(4):1332-1339.

36. Rivera RT, Pasion SG, Wong DT, Fei YB, Biswas DK: Loss of tumorigenic potential by human lung tumor cells in the presence of antisense RNA specific to the ectopically synthesized alpha subunit of human chorionic gonadotropin. J Cell Biol 1989, 108(6):2423-2434.

37. Rumpold H, Mascher K, Untergasser G, Plas E, Hermann M, Berger P: Transdifferentiation of prostatic stromal cells leads to decreased glycoprotein hormone alpha production. J Clin Endocrinol Metab 2002, 87(11):5297-5303.

38. Dirnhofer S, Berger C, Hermann M, Steiner G, Madersbacher S, Berger P: Coexpression of gonadotropic hormones and their corresponding $\mathrm{FSH}-$ and LH/CG-receptors in the human prostate. Prostate 1998, 35(3):212-220.

39. Fetissof F, Arbeille B, Guilloteau D, Lanson Y: Glycoprotein hormone alphachain-immunoreactive endocrine cells in prostate and cloacal-derived tissues. Arch Pathol Lab Med 1987, 111(9):836-840.

40. Berger P, Kranewitter W, Madersbacher S, Gerth R, Geley S, Dirnhofer S: Eutopic production of human chorionic gonadotropin beta (hCG beta) and luteinizing hormone beta (hLH beta) in the human testis. FEBS Lett 1994, 343(3):229-233. 
41. Toll H, Berger P, Hofmann A, Hildebrandt A, Oberacher H, Lenhof HP, Huber CG: Glycosylation patterns of human chorionic gonadotropin revealed by liquid chromatography-mass spectrometry and bioinformatics. Electrophoresis 2006, 27(13):2734-2746.

42. Stenman UH, Tiitinen A, Alfthan $H$, Valmu L: The classification, functions and clinical use of different isoforms of HCG. Hum Reprod Update 2006, 12(6):769-784.

doi:10.1186/1477-7827-9-114

Cite this article as: Zenzmaier et al.: Decreased levels of genuine large free hCG alpha in men presenting with abnormal semen analysis. Reproductive Biology and Endocrinology 2011 9:114.

Submit your next manuscript to BioMed Central and take full advantage of:

- Convenient online submission

- Thorough peer review

- No space constraints or color figure charges

- Immediate publication on acceptance

- Inclusion in PubMed, CAS, Scopus and Google Scholar

- Research which is freely available for redistribution

Submit your manuscript at www.biomedcentral.com/submit
() Biomed Central 